INSTITUTE OF FORESTRY • BELGRADE

INSTITUT ZA ŠUMARSTVO • BEOGRAD

SUSTAINABLE FORESTRY

COLLECTION 83-84, 2021
ODRŽIVO ŠUMARSTVO

ZBORNIK RADOVA 83-84, 2021

DOI: $10.5937 /$ SustFor2183037P

Original scientific paper

\title{
MORPHOLOGICAL VARIABILITY OF WILD SERVICE TREE (Sorbus torminalis (L.) Crantz) FRUIT AND SEEDS FROM THE AREA OF KOŠUTNJAK
}

\author{
Slavko PAVLOVIĆ ${ }^{1}$ Ivona KERKEZ JANKOVIĆl, Jovana DEVETAKOVIĆl, \\ Mirjana ŠIJAČIĆ-NIKOLIĆ ${ }^{l}$
}

\begin{abstract}
Wild service tree (Sorbus torminalis (L.) Crantz) is an autochthonous deciduous species that have highly valuated timber. It often occurs individually in oak and beech forests, but it is necessary to monitor the intensity of regeneration and presence in these forests. The fruits of this species are edible and medicinal, usually contain 2-4 seeds, which are characterized by dormancy. The fruits and seeds collected from trees from the area of Košutnjak (Belgrade, Serbia) were used in this study. This study aimed to determine the variability of fruits and seeds in the population. Length and width of fruit and also determined length, width, and thickness of the seed were measured. The dimensions of fruits and seeds from this population were by results reported in previous studies. The obtained results showed clear differences between trees in morphological attributes of fruits and seeds (OneWay ANOVA, $p<0,05$ ). The average fruit contained more than two seeds and a maximal number of seeds per one fruit was 5 . At one tree were recorded a high number of empty fruits. The obtained results indicate a high degree of genetic variability in this population, but also indicate the need for testing with other morphological and molecular markers.
\end{abstract}

Key words fruits and seeds, variability, morphological markers.

\footnotetext{
${ }^{1}$ BSc Slavko Pavlović, undergraduate student, MSc Ivona Kerkez Janković, Research Associate, Dr Jovana Devetaković, Assistant Professor, Dr Mirjana Šijačić-Nikolić, Full Professor, Faculty of Forestry, University of Belgrade, 11030 Belgrade, Republic of Serbia

Corresponding author: Dr Jovana Devetaković, e-mal: jovana.devetakovic@ @fb.bg.ac.rs
} 


\section{VARIJABILNOST MORFOLOŠKIH KARAKTERISTIKA PLODOVA I SEMENA BREKINJE (Sorbus torminalis (L.) Crantz) SA PODRUČJA KOŠUTNJAKA}

Izvod: Brekinja (Sorbus torminalis (L.) Crantz) je autohtona vrsta lišćara koja ima veoma cenjeno $i$ vredno drvo. Često se stablimično javlja u hrastovim i bukovim šumama, ali neophodno je pratiti intenzitet njenog obnavljanja i zastupljenost $u$ ovim šumama. Plodovi ove vrste su jestivi i lekoviti, sadrže obično 2-4 semena koja karakteriše dormantnost. U radu su korišćeni plodovi i semena brekinje sakupljeni sa stabala koja rastu na području Košunjaka (Beograd, Srbija). Cilj ovog istraživanja je da se utvrdi varijabilnost plodova i semena brekinje u ovoj populaciji. Plodovima je izmerena dužina $i$ širina i određen je broj semena koji se nalazi u plodu, a semenu su mereni dužina, širina $i$ debljina. Dimenzije plodova i semena iz ove populacije nalaze se u opsegu vrednosti koje su prijavljene u ranijim istraživanjima. Dobijeni rezultati su pokazali da postoje jasne razlike između stabala u krupnoći plodova $i$ semena (OneWay ANOVA, p<0,05). Broj semena u plodu maksimalno je iznosio 5, a u proseku se u plodu nalazilo više od dva semena. Kod jednog stabla je zabeležen veliki broj plodova bez semena. Dobijeni rezultati ukazuju na visok stepen genetičke varijabilnosti u ovoj populaciji, ali i ukazuju na potrebu za testiranjem drugim morfološkim i molekularnim markerima.

Ključne reči: brekinja, plodovi i seme, varijabilnost, morfološki markeri.

\section{INTRODUCTION}

Wild service tree (Sorbus torminalis (L.) Crantz) is a diploid $(2 \mathrm{n}=34)$, monoecious, heliophytic, fast-growing species, widespread in southern, western, and central Europe, northwestern Africa, and southeast Asia (Welk et al., 2016), with an altitude from 100 m.a.s.l. (Romania) to 2200 m.a.s.l. (Turkey). Current occurrence centers of this species are located in France and the Balkan region (Nicolescu et al., 2009). The limiting factor in the vertical distribution of this species is the amount of heat in the summer (Welk et al., 2016). In stands, it occurs individually (in the beech and pine forests) and in groups (in the oak forests) with an occurrence of 0.1 to 30 individuals/ha (Demesure-Musch, Oddou-Muratorio, 2004). This tree is widely indigenous in Serbia, represented as an accompanying species in the oak and beech forests up to $1500 \mathrm{~m}$ a.s.l. (Cvjetićanin and Perović, 2000). In terms of endangerment, it is categorized as a species "at-risk" (Banković et al., 2009), due to habitat fragmentation, possible disturbance of the genetic structure of populations, difficult natural regeneration, and poor competitiveness of the species (Demesure-Musch, Oddou-Muratorio, 2004).

Forest ecosystems are exposed to a constant process of fragmentation due to the implementation of other forms of land use (Tyrväinen, Miettinen, 2000). This type of anthropopresure is especially present in urban forest ecosystems (Raskovic, 2015), such as Kosutnjak. Forest areas in cities have a special value since they are one of the last refuges of flora and fauna and as such represent important ecosystems in terms of preserving diversity and integrity of nature with optimal land use to improve environmental quality (Milovanović et al., 2010). As one of the species of forest fruit trees, wild service tree represents an important 
ecosystem component from the aspect of biodiversity, nutrition of ornithofauna, and landscape appearance of the Košutnjak forest.

Wild service tree blooms during late spring and forms fruits that ripen in the fall of the same year. The flowers are hermaphroditic, and pollination is entomophilic. The fruits are apparent, ellipsoid (pear-shaped), brown with light spots (Cvjetićanin and Perović, 2000). According to Aldasoro et al. (1998), the fruit has a multilayered epidermis, which is a morphological characteristic that is unknown in other Sorbus species. The seed is located inside the fleshy fruit, has a pronounced dormancy of the embryo, and, as with other species of the genus Sorbus, characterized by the absence of endosperm (Regent, 1980). The fruits are edible, and their medical properties are well known. They are common food for birds, especially thrushes (Turdus $s p$.), which play a significant role in spreading seeds over long distances and thus gene exchange between populations (Demesure et al., 2000).

Given all the above factors, it is necessary to pay attention to its presence and monitor the potential and intensity of natural regeneration of this species, especially in urban forest complexes that are exposed to intense anthropogenic pressure. In this paper, we investigated the morphological characteristics of fruits and seeds from the population in the area of Košutnjak in Belgrade. The conducted research will give a clearer picture of the genetic diversity and morphological characteristics of fruits and seeds in this area.

\section{MATERIAL AND METHOD OF WORK}

The fruits were collected in the period 20 to 25 September 2020. from 5 wild service trees growing at Košutnjak area. The presence of 25 adult trees was recorded in this area (Picture 1). Collecting of seeds was possible only from 5 trees, which in the field were marked with the numbers BR10, BR11, BR13, BR14, and BR15 (Table 1).

Košutnjak forests are administratively located in two management units: MU "Košutnjak", which is managed by PE "Srbijašume" and MU "Šuma Košutnjak - Trim staza", which is managed by the Institute for sport and sports medicine of the Republic of Serbia. The total area of these management units is 346.74 ha (305.97 ha and 40.77 ha, respectively). Trees selected as test trees in this study grow in the area of MU "Šuma Košutnjak - Trim staza".

The fruits were collected by picking from the branches of the tree. The collected fruits (Picture 2) were stored in a plastic bag in the refrigerator for 2 weeks. From each of the 5 trees, 40 fruits were selected and length and width were measured, as well as the number of seeds in each fruit. The seeds were extracted from fruits and used for seed length, seed thickness, and seed width measurements (Figure 3). All measurements were performed using a digital nonius, with an accuracy of $0.1 \mathrm{~mm}$. The obtained data were processed in Statistica 7.0 software. Mean values of measured characteristics, also standard deviation, and minimum and maximum values were calculated for observed morphological characteristics of fruits and seeds. Differences between trees were tested using one-factor analysis of variance (OneWay ANOVA, $\mathrm{p}<0.05$ ), and grouping was performed by Tukey 
HSD post-hoc test. The performed dendrogram cluster analysis was used to observe the morphological closeness between the tested trees.

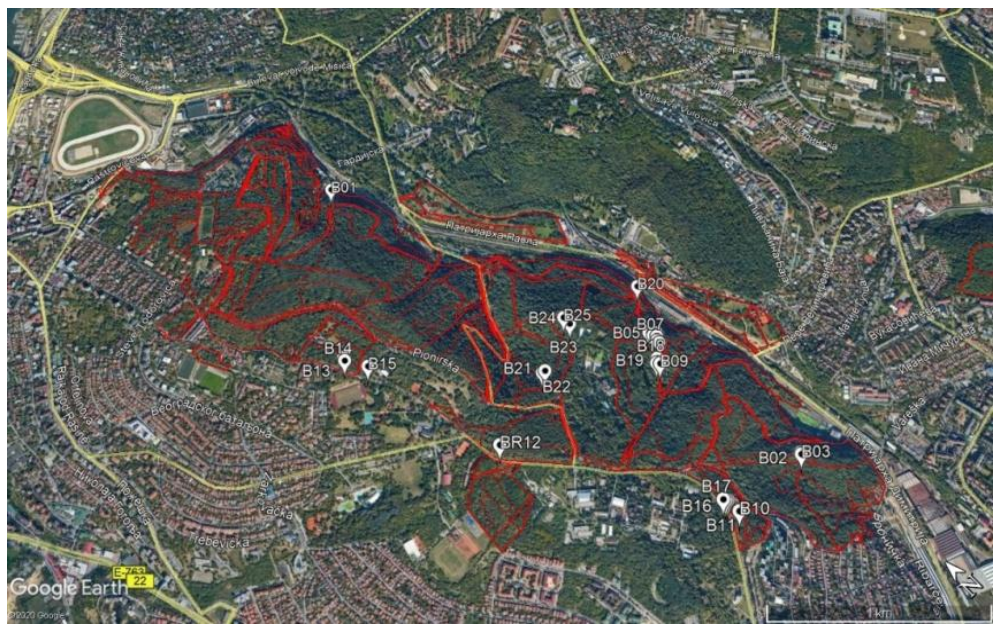

Figure 1. Map of trees on Košutnjak

Table 1. Marks, coordinates, dimensions and yield abundance for recorded trees

\begin{tabular}{|c|c|c|c|c|}
\hline $\begin{array}{c}\text { Mark on the } \\
\text { map }\end{array}$ & $\begin{array}{c}\text { Geographical } \\
\text { longitude }\end{array}$ & $\begin{array}{c}\text { Geographical } \\
\text { latitude }\end{array}$ & $\begin{array}{c}\text { Tree diameter } \\
\text { (cm) }\end{array}$ & $\begin{array}{c}\text { Tree height } \\
\text { (m) }\end{array}$ \\
\hline B10 & 44753083 & 20436712 & 25.5 & 9.0 \\
\hline B11 & 44753680 & 20436723 & 29.3 & 11.0 \\
\hline B13 & 44768890 & 20427299 & 36.0 & 8.5 \\
\hline B14 & 44768747 & 20427206 & 34.5 & 9.0 \\
\hline B15 & 44767881 & 20427940 & 31.2 & 12.0 \\
\hline
\end{tabular}

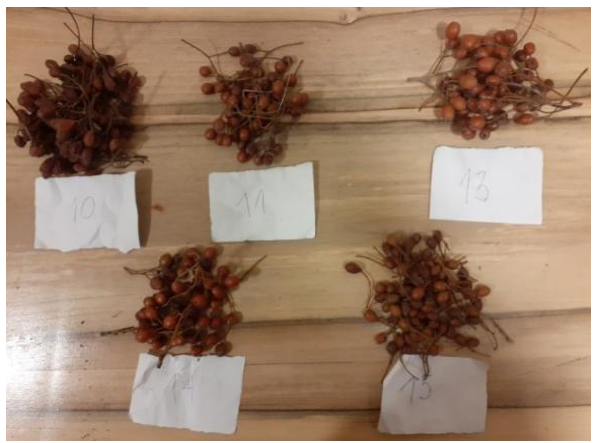

Picture 2. Sampled fruits

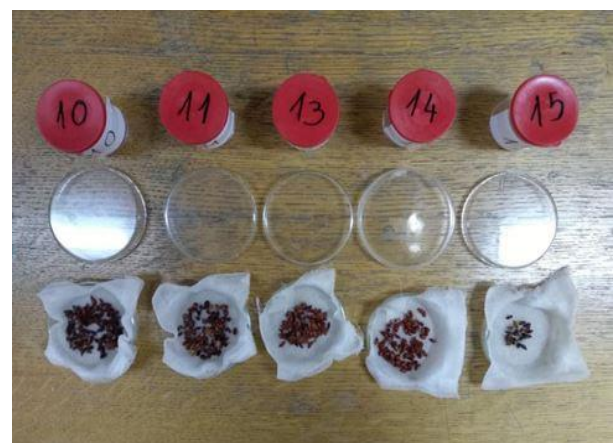

Picture 3. Extracted seeds from sampled fruits 


\section{RESULTS}

\subsection{Fruits morphological characteristics}

According to the morphological characteristics of the fruits (Table 2), tree BR13 had the highest mean values of fruit length $(13.33 \mathrm{~mm})$, and maximum fruit length $(17.3 \mathrm{~mm})$. The fruits from tree BR14 were the widest according to the average values of fruit width $(10.66 \mathrm{~mm})$. The lowest mean value of fruit length was recorded for fruits from tree BR11 $(11.29 \mathrm{~mm})$, while the lowest mean value of fruit width was in fruits from tree BR15 $(7.80 \mathrm{~mm})$. On average, the largest number of seeds in the fruit were observed in fruits originating from tree BR10 (2.46) and BR14 (2.51), and at least in tree number BR15 (1.14). A maximum of 5 seeds per fruit was extracted from fruits originating from trees BR10 and BR14. Fruits without seeds were recorded in all trees. The highest number of fruits without seeds was recorded in tree number BR15.

Table 2. Mean (standard deviation), maximum and minimum values of the observed characteristics of fruits

\begin{tabular}{|c|c|c|c|c|c|c|}
\hline \multirow{2}{*}{$\begin{array}{c}\text { Tree } \\
\mathrm{N}=\mathbf{2 0 0}\end{array}$} & \multicolumn{2}{|c|}{ Fruit length (mm) } & \multicolumn{2}{|c|}{ Fruith width (mm) } & \multicolumn{2}{|c|}{ Number of seeds in fruit } \\
\hline & $\begin{array}{c}\text { Mean value* } \\
\text { (sd) }\end{array}$ & $\min -\max$ & $\begin{array}{l}\text { Mean value* } \\
\text { (sd) }\end{array}$ & $\min -\max$ & $\begin{array}{l}\text { Mean value* } \\
\text { (sd) }\end{array}$ & $\min -\max$ \\
\hline BR10 & $14.36^{\mathrm{c}}(1.20)$ & $11.60-16.30$ & $8.75^{\mathrm{a}}(0.99)$ & $6.90-10.50$ & $2.46^{\mathrm{a}}(1.31)$ & $0.00-5.00$ \\
\hline BR11 & $11.29^{\mathrm{a}}(0.89)$ & $8.80-12.60$ & $8.91^{\mathrm{a}}(0.97)$ & $7.10-11.40$ & $2.05^{\mathrm{a}}(1.06)$ & $0.00-4.00$ \\
\hline BR13 & $13.33^{\mathrm{b}}(1.35)$ & $10.60-17.30$ & $10.04^{\mathrm{b}}(1.21)$ & $7.00-11.70$ & $2.03^{\mathrm{a}}(1.28)$ & $0.00-4.00$ \\
\hline BR14 & $12.98^{\mathrm{b}}(0.93)$ & $10.00-14.40$ & $10.66^{\mathrm{b}}(1.04)$ & $7.30-11.90$ & $2.51^{\mathrm{a}}(1.37)$ & $0.00-5.00$ \\
\hline BR15 & $11.91^{\mathrm{a}}(1.04)$ & $9.30-14.20$ & $7.80^{\mathrm{c}}(0.77)$ & $7.00-10.10$ & $1.14^{\mathrm{b}}(0.67)$ & $0.00-3.00$ \\
\hline
\end{tabular}

${ }^{*}$ Tukey HSD post-hoc test, $p<0.05$

\subsection{Seeds morphological characteristics}

From 200 fruits ( 5 trees $\times 40$ fruits) were extracted a total of 343 seeds (Figure 4). The mean value of seed length is highest in tree BR10 $(7.26 \mathrm{~mm})$ and lowest in tree BR11 $(5.40 \mathrm{~mm})$. The average thickness is highest at seeds from tree BR13 $(2.39 \mathrm{~mm})$, and the smallest in tree BR10 $(1.94 \mathrm{~mm})$ and BR15 $(1.94 \mathrm{~mm})$. The highest mean value of seed width was recorded in seeds from tree BR14 (3.83 $\mathrm{mm})$, and the smallest at tree BR15 $(2.71 \mathrm{~mm})$. The longest seed is recorded in tree BR10 (5.90-8.60 mm), and the shortest in tree BR11 $(4.10-6.90 \mathrm{~mm})$. The thickest seeds were recorded at trees BR13 $(1.20-3.40 \mathrm{~mm})$ and BR14 $(1.40-3.30 \mathrm{~mm})$, and the thinnest at tree BR15 $(1.00-2.70 \mathrm{~mm})$. The largest variations in thickness were observed in tree BR11 $(0.50-4.50 \mathrm{~mm})$. The widest seeds were recorded at tree BR13 $(2.80-4.80 \mathrm{~mm})$, and at the opposite is tree number BR15 which has the narrowest seed $(2.10-3.90 \mathrm{~mm})$. 
Table 3. Mean (standard deviation), maximum and minimum values of the observed characteristics of seeds

\begin{tabular}{|c|c|c|c|c|c|c|}
\hline \multirow{2}{*}{$\begin{array}{c}\text { Tree } \\
\mathbf{N}=\mathbf{3 4 3}\end{array}$} & \multicolumn{2}{|c|}{ Seed length $(\mathbf{m m})$} & \multicolumn{2}{|c|}{ Seed thickness (mm) } & \multicolumn{2}{|c|}{ Seed width $(\mathbf{m m})$} \\
\hline & $\begin{array}{l}\text { Mean value } \\
\text { (sd) }\end{array}$ & $\min -\max$ & $\begin{array}{c}\text { Mean value } \\
\text { (sd) }\end{array}$ & $\min -\max$ & $\begin{array}{l}\text { Mean value }{ }^{*} \\
\text { (sd) }\end{array}$ & $\min -\max$ \\
\hline BR10 & $7.26^{\mathrm{c}}(0.53)$ & $5.90-8.60$ & $1.94^{\mathrm{b}}(0.37)$ & $0.90-2.80$ & $3.42^{\mathrm{b}}(0.37)$ & $2.00-4.30$ \\
\hline BR11 & $5.40^{\mathrm{b}}(0.58)$ & $4.10-6.90$ & $2.27^{\mathrm{ac}}(0.67)$ & $0.50-4.50$ & $3.60^{\mathrm{ab}}(0.51)$ & $2.40-5.10$ \\
\hline BR13 & $6.56^{\mathrm{a}}(0.65)$ & $5.40-7.90$ & $2.39^{\mathrm{a}}(0.42)$ & $1.20-3.40$ & $3.75^{\mathrm{a}}(0.45)$ & $2.80-4.80$ \\
\hline BR14 & $6.22^{\mathrm{a}}(0.46)$ & $5.10-7.20$ & $2.31^{\mathrm{a}}(0.36)$ & $1.40-3.30$ & $3.83^{\mathrm{a}}(0.43)$ & $2.80-4.60$ \\
\hline BR15 & $6.11^{\mathrm{a}}(0.56)$ & $4.80-7.00$ & $1.94^{\text {bc }}(0.47)$ & $1.00-2.70$ & $2.71^{\mathrm{c}}(0.42)$ & $2.10-3.90$ \\
\hline
\end{tabular}

* Tukey HSD post-hoc test, $p<0.05$

\subsection{Differences between trees in the observed morphological characteristics of fruits and seeds}

Analysis of variance for observed characteristics of the fruits (length and width of fruit and number of seeds in fruits) and seeds (length, thickness and width of seed) shows significant differences between the trees (Table 4). Fruits and seeds originating from one tree were separated in relation to other trees, and all trees differ significantly in the observed morphological characteristics of fruits and seeds.

Grouping according to the Tukey post-hoc test showed a large number of groups for each of the observed morphological characteristics of fruits and seeds (Table 2 and Table 3).

Table 4. Analysis of variance for the observed characteristics of fruits and seeds (OneWay ANOVA, $p<0.05$ )

\begin{tabular}{|l|c|c|c|c|c|c|c|c|}
\hline \multicolumn{1}{|c|}{ Parameter } & $\begin{array}{c}\text { SS } \\
\text { Effect }\end{array}$ & df Effect & MS Effect & SS Error & df Error & MS Error & F & p \\
\hline Fruit length & 225.33 & 4 & 56.33 & 234.79 & 195 & 1.20 & 46.7858 & 0.0000 \\
\hline Fruit width & 150.47 & 4 & 37.62 & 196.77 & 195 & 1.01 & 37.2786 & 0.0000 \\
\hline Number of seeds in fruit & 73.83 & 4 & 18.46 & 264.93 & 195 & 1.36 & 13.5858 & 0.0000 \\
\hline Seed length & 159.89 & 4 & 39.97 & 102.19 & 338 & 0.30 & 132.2051 & 0.0000 \\
\hline Seed thickness & 13.04 & 4 & 3.26 & 75.32 & 338 & 0.22 & 14.6343 & 0.0000 \\
\hline Seed width & 22.79 & 4 & 5.70 & 65.02 & 338 & 0.19 & 29.6226 & 0.0000 \\
\hline
\end{tabular}

The dendrogram of cluster analysis (Graph 1) indicates the separation two groups of trees according to the observed morphological characteristics of fruits and seeds. In one group there are tree BR13 and BR14 which are grouped at a relatively short distance. Tree number BR10 is later connected with this group. Trees number BR11 and BR15 are grouped at a relatively large distance forming a separate group. 


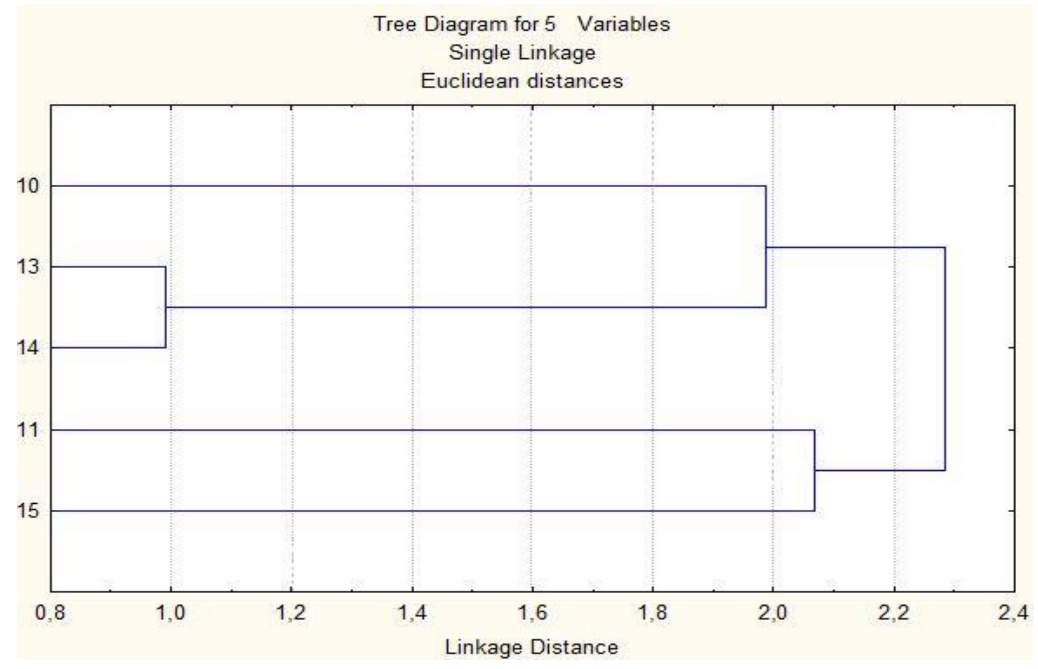

Graph 1. Dendrogram of cluster analysis

\section{DISCUSSION}

McAllister (2005), considers that the length of fruit can be very important and that it is more stable than the width, which varies depending on the availability of water and the number of viable seeds. In this study was found that there is equal variation, both in fruit length and fruit width. However, Bednorz (2006) states that the width of the fruit is more stable than the length, despite large variations in the number of seeds. Most often, in the examined populations, the fruits contained two seeds, but also fruit without seeds, and even fruits with six seeds each. The average number of seeds was 2-4 per fruit in our research, but a large number of fruits without seeds were recorded in fruits from tree 15. In several cases, 5 seeds per fruit were recorded (for seeds from trees 10 and 14). There are usually 2-4 seeds in one fruit (McAllister, 2005), which is confirmed in this research. Orsanić et al. (2009), recorded slightly larger fruits in three Croatian populations, but at the same time, the average number of seeds in yield from these populations was lower than in our study, and in all three populations it had a mean value below 2 seeds per fruit.

The measured values of seed length, thickness, and width in this study are in the range reported by Bednorz (2006), for seeds originating from 13 populations of this species in Poland. Research conducted in Bosnia and Herzegovina also shows a similar range of variation in the length and width of seeds (Hodzic et al., 2016).

Based on all observed morphological characteristics of yield and seeds, we can conclude that the most similar trees are 13 and 14, which are located close to each other in the field (Graph 1). However, we cannot conclude that the similarities and differences between the trees have a direct connection with the spatial arrangement of trees because these trees are most similar to tree 10, which is also at a greater distance from them compared to tested trees 11 and 15. A high degree of intrapopulation variability in populations in Europe has been observed using 
different molecular markers, and an overview of these studies is given in note (Hodzic et al., 2016). The results of our study indicate high intrapopulation variability.

\section{CONCLUSION}

Fruit dimensions are not necessarily an indicator of the number of seeds per fruit, but according to the average values, the largest fruits also contained the largest number of seeds on average. Morphological characteristics of fruits and seeds from trees growing in the area of Košutnjak showed a high degree of variability. All observed traits are in the range of values reported in previous studies. Differences between trees indicate a high level of genetic diversity that should be examined on a larger sample and using other morphological and molecular markers.

Acknowledgements: The paper was performed within the project „Identification and monitoring of the gene pool of rare, vulnerable and endangered plant species in the area of the NM ,Šuma Košutnjak" " funded by Secretariat for Environmental Protection - City of Belgrade, agreement No V-01 401.1-56 from 12.6.2019.

\section{REFERENCES}

Aldasoro, J. J., Aedo, C., Navarro, C. and Garmendia, F. M. (1998): The genus Sorbus (Maloideae, Rosaceae) in Europe and in North Africa: morphological analysis and systematics. Systematic botany, 189-212

Banković, S., Medarević, M., Pantić, D., Petrović, N., Šljukić, BB. and Obradović, S. (2009): The growing stock of the Republic of Serbia - state and problems. Bulletin of the Faculty of Forestry 100: 7-30

Bednorz, L. (2006): Morphological vatiability of fruits and seeds of Sorbus torminalis in Poland. Dendrobiology 57: 3-14

Cvjetićanin, R. i Perović, M. (2010): Dendrology practicum 265, Faculty of Forestry in Belgrade: 114 and 124. (In original: Cvjetićanina, R. I Perović, M. (2010): Praktikum iz dendrologije 265, Šumarski fakultet u Beogradu: 114 i 124)

Demesure, B., Le Guerroué, B., Lucchi, G., Prat, D. and Petit, R. J. (2000): Genetic variability of a scattered temperate forest tree: Sorbus torminalis L.(Crantz). Annals of Forest science, 57(1), 63-71

Demesure-Musch, B. and Oddou-Muratorio, S. (2004): EUFORGEN Technical Guidelines for genetic conservation and use for wild service tree (Sorbus torminalis). International Plant Genetic Resources Institute, Rome, Italy. 6 pages. 
Hodžić, MM., Kovač, E., Ballian, D. and Kvesić, S. (2016): Morphological characteristics of leaf, fruit and seed of wild service tree (Sorbus torminalis/L./Crantz) in Kakanj municipality. Naše Šume, 15(42/43): 14-23

McAllister, H. (2005): The Genus Sorbus: Mountain Ash and Other Rowans. Royal Botanic Gardens, Kew, Richmond, UK

Milovanović, B., Trikić, M.,Jovanović, B. et al. (2010): Study on the protection of the Monument of Nature "Miljakovac Forest". Belgrade: Institute for Nature Protection of Serbia (In original: Milovanović, B., Trikić, M., Jovanović, B. et al. (2010): Studija zaštite Spomenika prirode,, Miljakovačka šuma”. Beograd: Zavod za zaštitu prirode Srbije.)

Nicolescu, V. N., Hochbichler, E., Coello Gomez, J., Ravagni, S., \& Giulietti, V. (2009): Ecology and silviculture of wild service tree (Sorbus torminalis (L.) Crantz): a literature review. Die Bodenkultur, 60(3), 35-44

Oršanić, M., Drvodelić, D., Jemrić, T., Anić, I. and Mikac, S. (2009): Variability of morphological and biological characteristics of wild service tree (Sorbus torminalis $(L$. Crantz) fruits and seeds from different altitudes. Periodicum biologorum, 111(4): 495-504

Rašković, D. (2015): Anthropogenic impacts on the stability of the forest ecosystems in Belgrade-comparative analysis of Košutnjak Forest and Zvezdarska Forest. Гласник Српског географског друштва, 95(4), 195-214

Regent, B. (1980): Forest seed production. Yugoslav Agricultural and Forestry Center, Forest Production Service, 179 (In original: Regent, B. (1980): Šumsko sjemenarstvo. Jugoslovenski poljoprivredno šumarski centar, Služba šumske proizvodnje, 179)

Tyrvainen, L., Miettinen A. (2000): Property Prices and Urban Forest Amenities. Journal of Environmental Economics and Management. 39, 205-223

Welk, E., de Rigo, D., Caudullo, G. (2016): Sorbus torminalis in Europe: distribution, habitat, usage and threats. In: San-Miguel-Ayanz, J., de Rigo, D., Caudullo, G., Houston Durrant, T., Mauri, A. (Eds.), European Atlas of Forest Tree Species. Publ. Off. EU, Luxembourg, pp.e01090d+ 


\title{
MORPHOLOGICAL VARIABILITY OF WILD SERVICE TREE (Sorbus torminalis (L.) Crantz) FRUIT AND SEEDS FROM THE AREA OF KOŠUTNJAK
}

\author{
Slavko PAVLOVIĆ, Ivona KERKEZ JANKOVIĆ, Jovana DEVETAKOVIĆ, \\ Mirjana ŠIJAČIĆ-NIKOLIĆ
}

\section{Summary}

Wild service tree (Sorbus torminalis (L.) Crantz), $(2 \mathrm{n}=34)$, is heliophytic, fastgrowing species, widespread in southern, western, and central Europe, northwestern Africa, and southeast Asia from 100-2200 m.a.s.l. In stands, it occurs individually (in the beech and pine forests) and in groups (in the oak forests). This tree is widely indigenous in Serbia, categorized as a species "at-risk", and represented as an accompanying species in the oak and beech forests up to $1500 \mathrm{~m}$ a.s.l. As one of the species of forest fruit trees, wild service tree represents an important ecosystem component, especially in urban forests ecosystems, which are under the high rate of antropopressure.

In spring this species forms hermaphroditic flowers which are entomophilic pollinated and ellipsoid (pear-shaped), brown with light spots fruits will form and be ripen in the fall of the same year. The fruit has a multilayered epidermis and seeds have a pronounced dormancy of the embryo and, it is characterized by the absence of endosperm.

Due to habitat fragmentation, possible disturbance of the genetic structure of populations and difficult natural regeneration, and poor competitiveness of the species it is necessary to pay attention to its presence and monitor the potential and intensity of natural regeneration of this species, especially in urban forest complexes. In this paper, we investigated the morphological characteristics of fruits and seeds from the population in the area of Košutnjak in Belgrade.

The fruits were collected in September 2020. from 5 wild service trees growing at Košutnjak area. Trees were selected as test trees in this study grow in the area of MU "Šuma Košutnjak - Trim staza" (40.77 ha). The fruits were collected by picking from the branches of the tree. From each of the 5 trees, 40 fruits were selected. The number of seeds in each fruit, length and width of fruit, seed length, seed thickness, and seed width were measured using a digital nonius, with an accuracy of $0.1 \mathrm{~mm}$. Mean values of measured characteristics, standard deviation, minimum and maximum values were calculated in Statistica 7.0 software. Differences between trees were tested using OneWay ANOVA (p $<0.05)$, a grouping of trees was performed by Tukey HSD post-hoc test, also dendrogram cluster analysis was used to observe the morphological closeness between the tested trees.

From 200 fruits (5 trees x 40 fruits) were extracted a total of 343 seeds. Fruits without seeds were recorded in all trees. Analysis of variance for observed characteristics of the fruits and seeds showed significant differences.

Grouping according to the Tukey post-hoc test showed a large number of groups. The dendrogram of cluster analysis indicates the separation of two groups.

Morphological characteristics of fruits and seeds from trees growing in the area of Košutnjak showed a high degree of variability. All observed traits are in the range of values reported in previous studies. Differences between trees indicate a high level of genetic diversity that should be examined on a larger sample and using other morphological and molecular markers. 


\title{
VARIJABILNOST MORFOLOŠKIH KARAKTERISTIKA PLODOVA I SEMENA TEST STABALA BREKINJE (Sorbus torminalis (L.) Crantz) SA PODRUČJA KOŠUTNJAKA
}

\author{
Slavko PAVLOVIĆ, Ivona KERKEZ JANKOVIĆ, Jovana DEVETAKOVIĆ, \\ Mirjana ŠIJAČIĆ-NIKOLIĆ
}

\section{Rezime}

Brekinja (Sorbus torminalis (L.) Crantz), $(2 \mathrm{n}=34)$, je heliofitna, brzorastuća vrsta rasprostranjena u južnoj, zapadnoj i centralnoj Evropi, severozapadnoj Africi i jugoistočnoj Aziji od 100-2200 m n.v. Javlja se stablimično (u pojasu šumam bukve i borova) i grupimično (u pojasu hrastovih šuma). Autohtona je vrtsa u Srbiji, kategorisana kao "vrsta pod rizikom", zastupqljna kao prateća vrsta u hrastovim i bukovim šumama do $1500 \mathrm{~m}$ n.v. Kao jedna od šumskih voćkarica, predstavlja važnu komponentu šumskih ekosistema, posebno u urbanim šumskim kompleksima koji su izloženi visokoj stopi antropopritiska.

U proleće ova vrsta formira hermafroditne cvetove koji se oprašuju entomofilno, dok se plodovi eloipsoidnog (kruškolikog) oblika smeđe boje sa svetlim pegama formiraju i sazrevaju u jesen iste godine. Plodovi imaju višeslojni epidermis, a semenke imaju izraženu dormantnost embriona, kao i karakteristično odsustvo endosperma.

Usled fragmentacije staništa, mogućeg poremećaja genetske strukture populacija i otežane prirodne obnove i slabe konkurentnosti vrste, potrebno je obratiti pažnju na prisustvo ove vrste i pratiti potencijal i intenzitet prirodne obnove, posebno u urbanim šumskim kompleksima. U ovom radu istražene su morfološke karakteristike plodova i semena iz populacije sa područja Košutnjaka u Beogradu.

Plodovi su sakupljeni u septembru 2020. godine sa 5 samoniklih stabala. Selektovane individue nalaze se na području GJ. „Šuma Košutnjak - Trim staza“ (40,77 ha). Plodovi su sakupljani branjem sa grana. Sa svakog od 5 stabala odabrano je po 40 plodova. Broj semena u svakom plodu, dužina i širina ploda, dužina semena, debljina i širina semena izmereni su pomoću digitalnog nonijusa sa tačnošću od $0,1 \mathrm{~mm}$. Srednje vrednosti izmerenih karakteristika, standardne devijacije, minimalne i maksimalne vrednosti izračunate su u softveru Statistica 7.0. Razlike između stabala su testirane pomoću jednofaktorijalne analize varijanse (OneWay ANOVA, p <0,05), grupisanje stabala je izvršeno Tukei HSD post-hoc testom, takođe je korišćena denrogramska klaster analiza za posmatranje morfološke bliskosti između testiranih stabala.

Iz 200 plodova ( 5 stabala $\times 40$ plodova) izvađeno je ukupno 343 semena. Plodovi bez semena zabeleženi su na svim stablima. Analiza varijanse za uočene karakteristike plodova i semena pokazala je značajne razlike. Grupisanje prema Tukey post-hoc testu pokazalo je veliki broj grupa. Dendrogram klaster analize ukazuje na razdvajanje dve grupe.

Morfološke karakteristike plodova i semena drveća koje raste na području Košutnjaka pokazale su visok stepen varijabilnosti. Sve uočene osobine su u opsegu vrednosti zabeleženih u prethodnim studijama. Razlike između drveća ukazuju na visok nivo genetske raznolikosti koji bi trebalo ispitati na većem uzorku i koristeći druge morfološke i molekularne markere. 